\title{
Erratum to: The Dispositional Attribution of Customer Satisfaction through the Juxtaposition of QFD Aand Servqual in Service Industry Design
}

\author{
Fevi Syaifoelida ${ }^{1 *}$, Khairul Salleh Mohamed Sahari ${ }^{1}$, Hasril Hasini ${ }^{1}$, A.M Megat $\operatorname{Hamdan}^{2}$ and A.Z Syahmi ${ }^{1}$ \\ ${ }^{1}$ Department of Mechanical Engineering, Universiti Tenaga Nasional, (UNITEN) \\ ${ }^{2}$ Department of Mechanical Engineering, Universiti Pertahanan Nasional Malaysia (UPNM)
}

Original article:

MATEC Web of Conferences 135, 00034 (2017), DOI: 10.1051/matecconf/201713500034

Word "Aand" in the Title should be corrected to "and", and since the first author's name was missing, the authors' name should be replaced to:

Fevi Syaifoelida ${ }^{1 *}$, Khairul Salleh Mohamed Sahari ${ }^{1}$, Hasril Hasini ${ }^{1}$, A.M Megat Hamdan ${ }^{2}$, and A.Z Syahmi ${ }^{1}$ 